\title{
EXAMINING THE RELEVANCE OF JOB SATISFACTION ON KOLAKA BUDGET DRAFTING TEAM'S PERFORMANCE
}

\author{
Hj. Syamsuryani Syahrir ${ }^{1)}$, H. Basri Modding ${ }^{2)}$, H. Baharuddin Semmaila ${ }^{3)}$, H. Jobhar Bima ${ }^{4)}$ \\ ${ }^{1)} \mathrm{PhD}$ Candidate (Muslim University of Indonesia) Makassar, Indonesia \\ ${ }^{2,3,4)}$ Lecturer in Management Science, Muslim University of Indonesia, Indonesia
}

\begin{abstract}
The purpose of this study is to analyze the effect of competence, discipline and emotional intelligence on job satisfaction of local government budget team's, to analyze the influence of competence, discipline, emotional Intelligence and job satisfaction on local government budget team's performance. The research was conducted at Kolaka district government with population of 468 local government budget drafting team and sample of 250 respondents using Slovin formula. The result data of the questionnaire were analyzed using Structural Equation Model (SEM) with AMOS assistance 18. The result of the research found that directly, competence and emotional intelligence have positive and significant effect on job satisfaction, competence have positive and significant on performance, discipline has positive and insignificant effect on job satisfaction and performance, emotional intelligence have positive and insignificant effect on performance, and job satisfaction have positive and insignificant effect to performance. In testing the indirect effect provides evidence that discipline and emotional intelligence have a positive and significant effect on performance with mediation of job satisfaction, while other indirect effects show different results. An important factor in the creation of performance is job satisfaction.
\end{abstract}

Keywords: Competence, discipline, emotional intelligence, satisfaction, performance

\section{INTRODUCTION}

The development of a nation requires asset called human resource substantial, this resource is very important in determining the success of a regional government development. Human resources play an important role in realizing a planned, programmed and sustainable development in achieving its goals for the welfare of people's lives. Given the important role of human resources in the development of local government, the employees as the civil servants Apparatus (ASN) are required to continue to contribute greatly in the development of local 
International Journal of Arts and Humanities

ISSN: 2581-3102

Volume:02, Issue:05 "May 2018"

government, including in this case Kolaka district government, especially in managing development activities requiring local use resources government budget in accordance with the allocation based on the use and utilization for regional development both for the development of the public sector and the government sector itself. The existence of human resources needs to be utilized and used by using the concept of human resource management. Terry (2008: 54) states that human resources are an important part of management that must be utilized and used to realize organizational goals.

The human resources that exist in a government agency, it should be utilized and used to realize the goals of the organization. Just as employees at 25 districts in Kolaka district government need to be professionally managed to utilize and use the proportionally managed revenue and expenditure budget. Therefore, the local government budgeting team needs to improve its performance according to the level of job satisfaction that is directly and indirectly influenced by the employee's competence, discipline in work and emotional intelligence of employees in facing the dynamics of their work. The phenomenon that is found today in 25 offices in the Government of Kolaka, especially on employee team-budgeting local government budget shows no gaps experienced by employees, this gap shows that the editorial team of the budget has performance achievement is still low in accordance with the achievement the work shown by the employee is viewed from the quantitative assessment of the amount of completed budgeting work, the low quality of budget compilation, the inefficient preparation of the budget in time, the ineffective use of budget is not effective and the level of work loyalty among the employees still low in budgeting. As a result of the low performance of local government budget drafting staff, budget utilization and allocation is often delayed and local development activities are often delayed from the scheduled schedule.

The data shows that became the performance phenomenon of Kolaka budget drafting team's performance which in the last five years shows the realization of achievement not according to the expected target $>95$ percent that can be realized. The realization of achievement value by civil servants work objective (SKP) which stated criteria very reasonable. The fact shows the realization of the achievement of employee performance has not been able to achieve according to the expected target. Realization of achievement based on employee job target criteria seen from the work in quantity in five years shows that achievement is still below 95 percent that is 84.4 percent until 90.5 percent. The quality achieved is still 85.2 percent until 93.5 percent, the use of budget completion time that can be achieved between 85.5 percent until89.2 percent. Effective utilization of budget achieved between 84.2 percent until $90.2 \%$, and achievement seen from the level of employee loyalty in the preparation of local government budget achieved between 84.2 percent until 88.4 percent. Overall, within five years it was concluded that the realization of the performance of the local government budgeting team's employee has not 
International Journal of Arts and Humanities

ISSN: 2581-3102

Volume:02, Issue:05 "May 2018"

reached the very reasonable criteria target above 95 percent of the criteria standard set as very reasonable criteria.

The research gap indicates that the budget drafting team's performance is still low, so it is necessary for the management of personnel resources of the drafting team to improve and improve the achievement of the performance by considering the theory of work achievement proposed by Schemerhorn, Hunt \& Osborn (2007: 66) that the success of an organization in realizing its objectives is judged by the performance of the outcomes achieved. This theory becomes a consideration for researchers that in the assessment of employee performance measured based on the achievement of work in quantity, quality, efficiency, effectiveness and loyalty according to organizational goals. Assessment of the performance of employees who did not achieve the expected targets has been linked to several previous studies which show that the decline in performance is influenced by job satisfaction, competence, discipline and emotional intelligence.

As a conducted by Markus Harry (2012) which recommends the results of research that the competence, discipline and emotional intelligence have a positive and insignificant effect on employee performance (Hasanuddin \& Sjahruddin, 2017). In addition, Anik Suwarni (2008) who recommends the results of competence research, emotional intelligence and discipline has a negative and significant impact on employee performance. The phenomenon of performance appraisal is still low above; this is not apart from the low level of job satisfaction of employees in carrying out their work as a team of local government budget drafter on Kolaka district government. The fact that employee job satisfaction is still low; this can be seen from the responses expressed by employees on the work done as a team of local government budget compilers. The form of employee's dissatisfaction is often indicated by complaining about routine jobs that are considered unattractive and boring, employees in their work do not dare to take the challenge of work at risk, employees are less satisfied because rarely achievers in work, employees often complain about the low value of incentive rewards that are not commensurate with reply services gained, and employees are less satisfied because they are seldom promoted for the success of work that is commonly achieved.

These are forms of dissatisfaction that employees often complain about, thereby affecting employee performance degradation. Understanding the performance of employees who decreased due to low employee job dissatisfaction, then the human resource management needs to apply the theory of work expectations or so-called the two factor theory (Herzberg proposed by Rivai, 2008: 255) that satisfaction and dissatisfaction are things different. The manifestation of this satisfaction depends on the expectations of exciting job interest, work challenges, achievements, rewards and promotional work achieved. Relation with some previous research 
International Journal of Arts and Humanities

ISSN: 2581-3102

Volume:02, Issue:05 "May 2018"

which examined about low satisfaction caused the performance did not increase; Moore (2011) with the recommendation of job satisfaction research has a negative and significant effect on employee performance. While the study by Stewart (2010) which shows job satisfaction has a positive and insignificant effect on performance. Seeing the phenomenon of decreased employee performance and low job satisfaction, this is not apart from the influence of competence, discipline and emotional intelligence possessed by employees who are still low.

As seen in some facts shown that the competence of employees is still low because there are still found employees who have the level of working knowledge in the field of local government budget preparation that has not been in accordance with the background and discipline that has, so the level of knowledge absorption is still low in the field of preparation. There are still employees with low skill level especially in planning and reporting of budget preparation, there are many employees who do not have enough professional experience to do local government budget preparation, and there are still employees in taking work attitude not yet mastering the work of arranging local government budget well. Due to the low competence of employees in carrying out activities as a team of budget compilers, causing many employees who are less satisfied with the work done and the achievement of its performance is still low. Considering these facts and facts, the human resource management of the local government budget team needs to apply the theory of window competence introduced by Donald (2010: 189) states the competence of a person to realize satisfaction and performance seen in four sides namely knowledge, skills, experience work and attitude mastery to achieve organizational goals. This theory is a consideration to fix and improve the competence of employees in carrying out their work in accordance with the ability to develop its potential in improving job satisfaction and performance.

The associations with several previous studies that examine the competence of job satisfaction and performance, the researchers (Mohammad Zaid Mustafa, 2014; Soleiman, 2012) recommendation of competence research and emotional intelligence have positive and insignificant effect on employee performance. Marcus Harry's (2012) which shows competence has a negative and insignificant effect on performance. The cause of low employee job satisfaction and declining performance is also caused by the low influence of work discipline employees in carrying out work as a team of local government budget drafter Kolaka district government. The fact that it is often found that there are some less disciplined employees in the work, have less diligent habits in working (high laziness level of work), usually employees willing to work if ordered by the leadership, attendance levels in less usual jobs after absence of employees place or not engage in work activities together with friends of a working team, there are among employees in completing the work not in time usual postponed the work given, employees also there are often not obey the agreed consensus of work, often violating the rules 
International Journal of Arts and Humanities

ISSN: 2581-3102

Volume:02, Issue:05 "May 2018"

of work which already exist, and the low level of sanctions that are rarely done, so that employees often do undisciplined work repeatedly. This is what causes the discipline of employee work is low and certainly gives effect to the low level of job satisfaction and employee performance decreased.

Looking at the facts that indicate that the work discipline of the local government budget compiler team is still low and gives the effect of low employee job satisfaction and employee performance decreases, then the human resources management need to apply disciplinary theory (Berdmend, 2007: 39) which states there are five considerations in providing work discipline assessment. These considerations include discipline in craft, attendance, timeliness, organizational consensus compliance and imposition of sanctions. The implementation of these five principles of discipline is the key to the success of the organization to realize its objectives. This theory is necessary for employees to improve and improve their understanding of the work discipline that must be actualized in the face of their daily work as a team of local government budget compilers. Relation with previous research which examined about discipline to job satisfaction and performance, Brian Mark (2012) provide evidence the discipline has negative and insignificant effect to satisfaction and achievement of employee performance. Soleiman Yahyazadeh (2012) which shows employee work discipline gives a direct influence on the performance of employees positively and significantly. The phenomenon is also seen to be the cause of low job satisfaction and employee performance decreased from the team of authorship caused by emotional intelligence possessed by employees in the face of the dynamics of work and work risk, there are still employees who have not been able to control or emotional control in carrying out its work, so the work generated does not provide satisfaction and improve employee performance. The fact that is often found there partial employees who are not able to develop emotional intelligence according to the level of awareness of himself in understanding and addressing the meaning of the job mandated, there are still employees who have not been able to set itself in accordance with the potential and the ability it has, there are still employees who have not clear the motive of himself in working towards the goals and objectives of work to be achieved, a sense of empathy in the low work and social skills possessed by the employee has not been able to create a harmonious social interaction with colleagues, so that employees difficult to handle and manage emotional intelligence to improve job satisfaction and performance.

Considering the low emotional intelligence conditions of employees in controlling and controlling the potential of emotional intelligence, management needs to consider applying the emotional intelligence theory (Goleman, 2002: 66) that emotional intelligence is the ability to recognize the feelings of oneself and the feelings of others, the ability of self-motive and the ability to manage emotions well to oneself in relation to others. This theory becomes important 
International Journal of Arts and Humanities

ISSN: 2581-3102

Volume:02, Issue:05 "May 2018"

to actualization in each employee for emotional intelligence possessed able to have an influence on improving job satisfaction and employee performance. The relation with some previous research that examined about emotional intelligence to job satisfaction and performance, emotional intelligence have negative and insignificant effect to the satisfaction (Moyosola, 2014). Similarly Danang (2014) shows that emotional intelligence has a negative and insignificant effect on job satisfaction and employee performance.

\section{LITERATURE REVIEW}

\section{Human Resources Management}

Understanding the concept of human resource management, must first understand the meaning of management and human resources. The concept of management is universal by using a scientific framework, which includes its principles and principles. If a manager has knowledge of the fundamentals of management and ways of implementing it, it will be able to carry out management functions effectively (Dessler, 2006: 15). The word manage itself comes from Italian, maneggio which is adopted from the Latin managiare derived from the word manus meaning hand. The concept of management is easy to define. Until now found a definition of management that is truly universally acceptable. Cray (2007: 151) states that management is working with people to achieve organizational goals with the performance of the functions of planning, organizing, staffing, leading and controlling. Dessler (2007: 22) defines human resource management as a management activity that includes utilization, development, assessment, and reward for human being as an individual member of the organization. Human resource management involves designing systems of planning, staffing, career management, performance evaluation, employee compensation and employment relationships as well as human and organizational matters. Human resource management involves all management practices that can directly affect the organization.

Competence

Competence becomes an important part of the success of human resources in realizing organizational goals. Competence comes from the word competent which means able to match with the word ability. This competence is related to the potential of individual human resources in behaving and acting to achieve its goals (Walker, 2007: 77). Competence viewed from the orientation of quality is reflected from four aspects of knowledge, skills, experience and work mastery. Harry (2011: 95) states to see the quality orientation of individual human resource competencies judged from the knowledge of work understood in accordance with the level of education held, the skills of various education and training that followed, the experience of the work period and the mastery of work based on diligence owned. Gully (2008: 71) states that the 
International Journal of Arts and Humanities

ISSN: 2581-3102

Volume:02, Issue:05 "May 2018"

elements that build competence in the form of knowledge work, skills, experience and attitude in the mastery of work.

Work discipline

Etymologically the discipline comes from disciple. Discipline is a particular condition in which people belonging to the organization are subject to the existing rules with pleasure. According to Pridjodarminto (2011: 15)) discipline is a condition created and formed through the process of a series of behaviors that show the value of obedience, obedience, order and order. Because it is united in the individual, then the attitude or deeds performed no longer or at all not perceived as a burden, otherwise will burden if not do as usual. This discipline has become part of the behavior in human life. Such disciplinary attitudes and behaviors are created through the process of building through the family, education and experience or the introduction of exemplary environment. Discipline will make the individual know how to distinguish what should be done must be done, which may be done, which should not be done (because it is prohibited). An organization needs guidance for employees to prevent violations of the established provisions. Work discipline applied as a communication tool as proposed by Barata (2008: 44) that the discipline of work is a tool used to change a behavior as well as an effort to raise awareness and willingness of a person to comply with all applicable rules and social norms.

Emotional Intelligence

The term emotional intelligence has become popular since its introduction in 1995 by Goleman (2002) through his book Emotional Intelligence - Why It Can Matter More Than IQ. Actually this term has appeared before and as terminology used in Wayne Payne's thesis in 1985. Goleman (2002: 58) mentions in addition to intellectual intelligence (intellegence quotient) there are other intelligences that help a person's success (emotional quotient). Even it is specifically said that emotional intelligence is more involved in success than intellectual intelligence. Intelligence includes the ability to read, write, count, as the narrow path of word skills and numbers that focuses on formal education (school), and actually leads one to achieve academic success (becoming a professor). But the definition of the success of life is not merely this. New views are growing: there are other intelligences beyond IQ, such as talent, social observation acumen, social relationships, emotional maturity, etc. which should also be developed. Emotional intelligence includes self-control, passion and persistence, and the ability to motivate oneself and survive frustration, the ability to control impulses and emotions, not exaggerate fun, regulate moods and keep stress loads from crippling thinking ability, to reading the deepest feelings of others (empathy) and praying, to maintain the best possible relationships, the ability to resolve conflicts, and to lead. These skills can be taught to children. People, who are under the impulse of a lack of self-control, suffer from the inability of moral control. 
International Journal of Arts and Humanities

ISSN: 2581-3102

Volume:02, Issue:05 "May 2018"

\section{Job Satisfaction}

Understanding the importance of job satisfaction in the organization then satisfaction factor satisfied choice is more a top priority without ignoring the satisfaction (hygiene factors). Luthans (2007: 119) states maintaining job satisfaction developed by an organization identical to the choice of activities are satisfied because the job is interesting, satisfied with the work challenges faced, satisfied due to achievements, satisfied because the award in the form of recognition of work and satisfied in assume job responsibilities. The five indicators covering exciting work, work challenges, achievement, compensation and promotion as an indicator are generated to assess job satisfaction. Means that job satisfaction will be fulfilled if everyone is able to produce an exciting job, satisfied with the challenges of work encountered, giving appreciation for achievement, satisfied to get compensation and satisfied to get promotion of job title (Hersey, 2007: 46). Job satisfaction only manifests if one runs organizational activities in accordance with the dynamics of work that occurs to generate disclosure of feelings based on the level of assessment of the work of interest, challenges faced, achievement, receive compensation and promoted, satisfied work (Hersey (2007: 47). Assessment of job satisfaction made after the individual assesses the work itself in accordance with the interest or interest to work. Furthermore, the assessment of work that is satisfactory or not depends on the challenges of work encountered. Including job satisfaction is assessed based on high appreciation for the achievement of achievement, which requires compensation to feel satisfied individual, not apart from promotion of the position mandated (Dekker 2007: 92).

\section{Performance}

The word performance of the translation employee of performances according to Rivai (2008: 14) the root of the word to perform meaning to produce, achieve, target and optimize activities (to result, achieve, targeting, evaluation); perform, run, execute (to do or carry out, execute); fulfill or perform the obligations of an intent or vow (to discharge of fulfill; as vow); implement or refine the responsibility (to execute or complete an undertaking); and do something expected by someone or machine (to do what is expected of a person machine). Bennardin \& Russell (2012: 88) provide an understanding of employee performance is a record of the results obtained from certain job functions or activities over a certain period of time. Gibson (2013: 355) states that employee performance is a work related to organizational goals in determining the outcome in quantity, quality, efficient, effective and in accordance with the level of personnel compliance in carrying out the structural and functional positions of the whole range of personnel within the organization. Furtwengler (2004: 85) states the performance of employees is the level of achievement of results on the implementation of certain tasks as intended. Irawan (2011: 46) states employee performance is the result of concrete work that can be observed and measured 
International Journal of Arts and Humanities

ISSN: 2581-3102

Volume:02, Issue:05 "May 2018"

according to targets and expected realization. Dessler (2011:39) states employee performance is the achievement of optimal results according to measurable measurement standards. Cleveland (2008: 12) states employee performance appraisal is the same as assessing the quality of work achieved. Assessment of the quality of work is assumed based on the satisfaction of the work performed based on the unit of action or changes that occur from the assessment of work. This view has relevance to quality theory (Ohara's, 2004: 52) that quality is a proof of employee performance that is maintained. According to Donnelly, Gibson \& Ivancevich (2004: 60) employee performance is assessed based on the results achieved according to the unit of time that produces work efficiency. Activities performed efficiently are an assessment of employee performance results in accordance with the quantity and quality of using work time.

\section{METHODS}

This research is designed to answer the problems that have been formulated and the objectives to be achieved and test the hypothesis. This research was conducted at Kolaka Regency Government as research object to see the influence of competence, discipline and emotional intelligence on job satisfaction and performance of local government budget compiler team. The study time is scheduled for four months from September to December 2017. The type of data in this study consists of primary and secondary data. Source of data obtained from the parties related to this research. The intended party is the Kolaka district government on the work unit of the budget drafting team's in obtaining various information that support the completeness of the data. Data collection techniques used is observations, questionnaires, interviews and documentation. The population in this study is the observation universe relating to the whole of Kolaka budget drafting team's consisting of two Secretariat, 25 officials and 5 work units amounting 668 people. Slovin formula obtained the number of respondents as many as 250 people. Data analysis techniques used in explaining the phenomenon in this research is descriptive statistical analysis techniques and Structural Equation Model (SEM) with AMOS assistance 18 .

\section{RESULTS}

Based on the method of determining the value of the model, the first model testing variables are grouped into exogenous variables and endogenous variables. An exogenous variable is a variable whose value is determined outside the model. Included in the group of exogenous variables are competence, discipline and emotional intelligence, while those belonging to endogenous variables are job satisfaction and performance. The model is said to be good when the hypothetical model development is theoretically supported by empirical data. The result of SEM analysis is complete can be seen in the following figure: 
International Journal of Arts and Humanities

ISSN: 2581-3102

Volume:02, Issue:05 "May 2018"

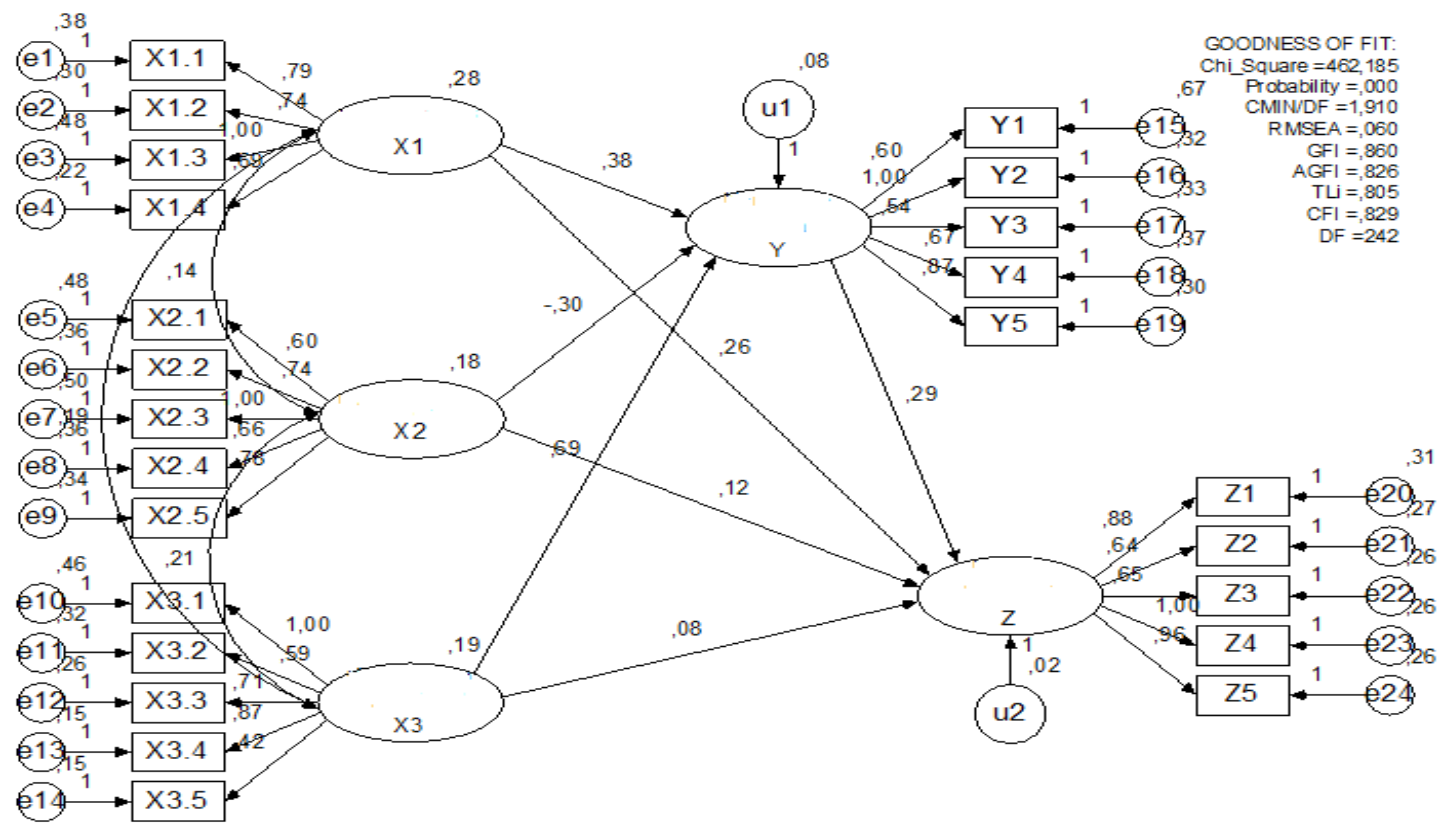

Fig. 1: First model

The model evaluation shows from eight criteria of goodness of fit indices seen the value of chisquare is still large and seen some criteria not in accordance with the cut off value determined, so that modification is done by correlating between error indicators in accordance with the instructions of modification indices. The results of the analysis after the final model are obtained as follows: 
International Journal of Arts and Humanities

ISSN: 2581-3102

Volume:02, Issue:05 "May 2018"

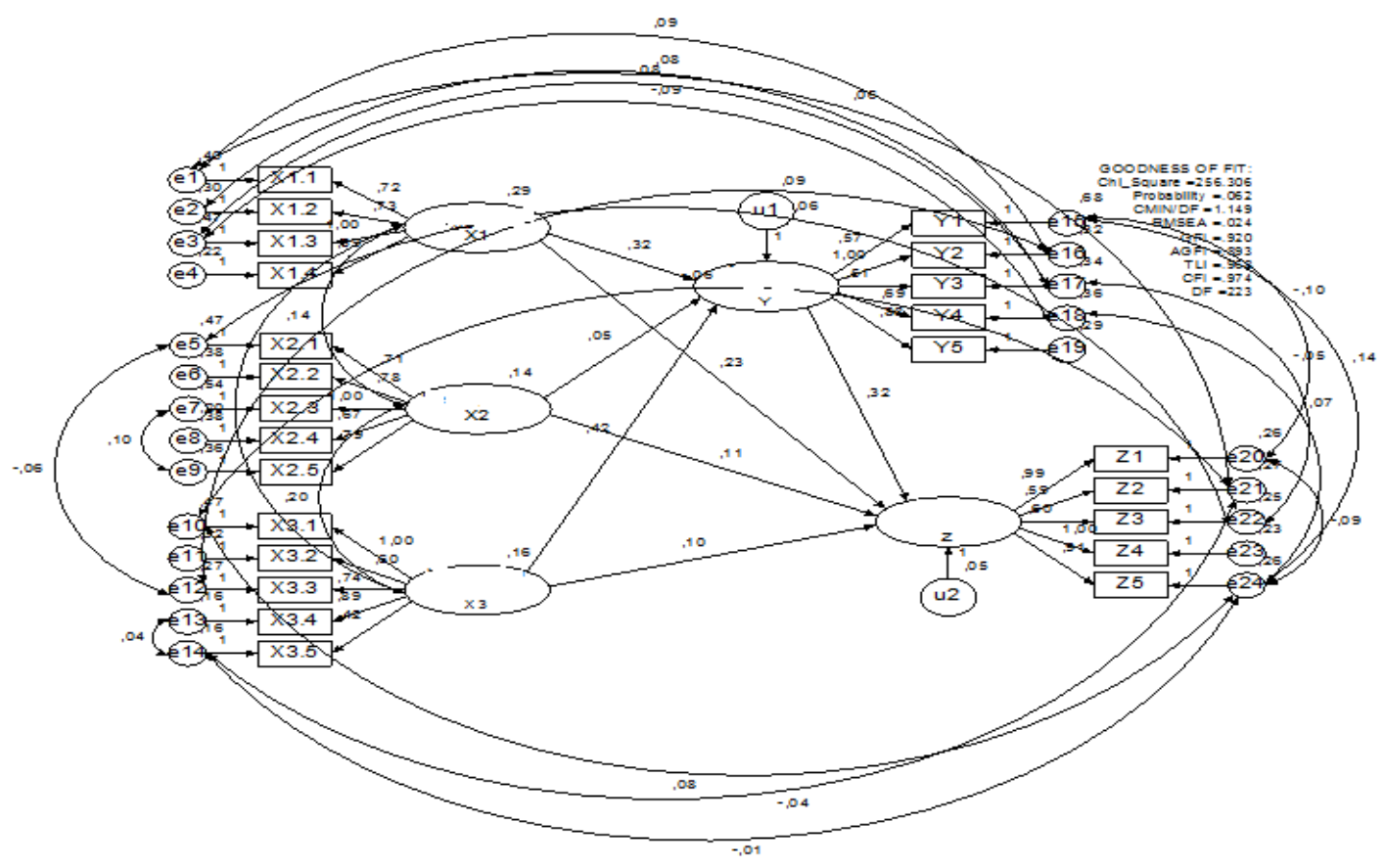

Fig. 2: Final model

The model test results presented in Figure 2 are evaluated based on the goodness of fit indices in Table 1 with the presented criteria model and its critical value that have data conformity.

Table 1: Goodness of fit overall model

\begin{tabular}{ccccc}
\hline $\begin{array}{c}\text { Goodness of fit } \\
\text { index }\end{array}$ & Cut-off Value & Early Model $*$ & Final Model * & Remarks \\
\hline$\chi^{2}-$ Chi- & Expected to be & $562,185(0,05: 242$ & $256,306(0,05: 223$ & Good \\
square & Small & $=279,288)$ & $=258,837)$ & \\
Probability & $\geq 0.05$ & 0,000 & 0,062 & Good \\
CMIN/DF & $\leq 2.00$ & 1,910 & 1,149 & Good \\
RMSEA & $\leq 0.08$ & 0,060 & 0,024 & Good \\
GFI & $\geq 0.90$ & 0,860 & 0,920 & Good \\
AGFI & $\geq 0.90$ & 0,826 & 0,893 & Marginal \\
CFI & $\geq 0.94$ & 0,829 & 0,974 & Good \\
TLI & $\geq 0.94$ & 0,805 & 0,968 & Good
\end{tabular}


International Journal of Arts and Humanities

ISSN: 2581-3102

Volume:02, Issue:05 "May 2018"

The result of model evaluation for the first stage shows that from eight criteria goodness of fit indices there are two that have met the criteria of cut off value, starting from CMIN / DF and RMSEA, so modification of model is needed according to the instructions of modification indices. Modification Indices (MI) is a calculation to make changes to a number, where the numbers below indicate the minimum value of chi-square that will fall if the corresponding variable is connected. Based on the empirical model proposed in this study can be tested against the hypothesis proposed through the testing of path coefficients in the structural equations model.

Table 2: Hypothesis testing

\begin{tabular}{|c|c|c|c|c|c|c|c|}
\hline \multirow{2}{*}{ Independent } & \multirow{2}{*}{ intervening } & \multirow{2}{*}{ Dependent } & \multicolumn{5}{|c|}{ Standardized Regression } \\
\hline & & & $\mathrm{p}$-value & Direct & Indirect & Total & Remarks \\
\hline $\begin{array}{l}\text { Competence } \\
\qquad\left(\mathrm{X}_{1}\right)\end{array}$ & & $\begin{array}{c}\text { job } \\
\text { satisfaction } \\
\text { (Y) }\end{array}$ & 0,025 & 0,373 & & 0,373 & $\begin{array}{c}\text { positive and } \\
\text { significant }\end{array}$ \\
\hline $\begin{array}{l}\text { Discipline } \\
\qquad\left(\mathrm{X}_{2}\right)\end{array}$ & & $\begin{array}{c}\text { Job } \\
\text { satisfaction } \\
(\mathrm{Y})\end{array}$ & 0,709 & 0,042 & & 0,042 & $\begin{array}{l}\text { positive and } \\
\text { insignificant }\end{array}$ \\
\hline $\begin{array}{c}\text { Emotional } \\
\text { intelligence } \\
\qquad\left(\mathrm{X}_{3}\right)\end{array}$ & & $\begin{array}{c}\text { Job } \\
\text { satisfaction } \\
\text { (Y) }\end{array}$ & 0,004 & 0,366 & & 0,366 & $\begin{array}{c}\text { positive and } \\
\text { significant }\end{array}$ \\
\hline $\begin{array}{l}\text { Competence } \\
\qquad\left(\mathrm{X}_{1}\right)\end{array}$ & & $\begin{array}{c}\text { Performance } \\
\text { (Z) }\end{array}$ & 0,035 & 0,319 & & 0,319 & $\begin{array}{c}\text { positive and } \\
\text { significant }\end{array}$ \\
\hline $\begin{array}{l}\text { Discipline } \\
\qquad\left(\mathrm{X}_{2}\right)\end{array}$ & & $\begin{array}{c}\text { Performance } \\
\text { (Z) }\end{array}$ & 0,262 & 0,105 & & 0,105 & $\begin{array}{l}\text { positive and } \\
\text { insignificant }\end{array}$ \\
\hline $\begin{array}{c}\text { Emotional } \\
\text { intelligence } \\
\qquad\left(\mathrm{X}_{3}\right)\end{array}$ & & $\begin{array}{c}\text { Performance } \\
\text { (Z) }\end{array}$ & 0,355 & 0,098 & & 0,098 & $\begin{array}{l}\text { positive and } \\
\text { insignificant }\end{array}$ \\
\hline $\begin{array}{c}\text { Job } \\
\text { satisfaction } \\
\text { (Y) }\end{array}$ & & $\begin{array}{c}\text { Performance } \\
\text { (Z) }\end{array}$ & 0,021 & 0,379 & & 0,379 & $\begin{array}{c}\text { positive and } \\
\text { significant }\end{array}$ \\
\hline $\begin{array}{l}\text { Competence } \\
\qquad\left(\mathrm{X}_{1}\right)\end{array}$ & $\begin{array}{c}\text { Job } \\
\text { satisfaction } \\
\text { (Y) }\end{array}$ & $\begin{array}{c}\text { Performance } \\
\text { (Z) }\end{array}$ & 0,053 & 0,319 & 0,141 & 0,46 & $\begin{array}{l}\text { positive and } \\
\text { insignificant }\end{array}$ \\
\hline $\begin{array}{l}\text { Discipline } \\
\qquad\left(\mathrm{X}_{2}\right)\end{array}$ & $\begin{array}{c}\text { Job } \\
\text { satisfaction } \\
\text { (Y) }\end{array}$ & $\begin{array}{c}\text { Performance } \\
\text { (Z) }\end{array}$ & 0,024 & 0,105 & 0,016 & 0,121 & $\begin{array}{c}\text { positive and } \\
\text { significant }\end{array}$ \\
\hline Emotional & Job & Performance & 0,036 & 0,098 & 0,139 & 0,237 & positive and \\
\hline www.journal- & ijah.org & Copyright $\mathbb{C}$ & IJAH 2018 & All right $r$ & erved & & Page 363 \\
\hline
\end{tabular}


ISSN: 2581-3102

Volume:02, Issue:05 "May 2018"

intelligence satisfaction

(Z)

significant

$\left(\mathrm{X}_{3}\right)$

(Y)

Based on the p-value on the influence of indirect effect independent variables through the intermediate variables to the dependent variable following Sobel test results:

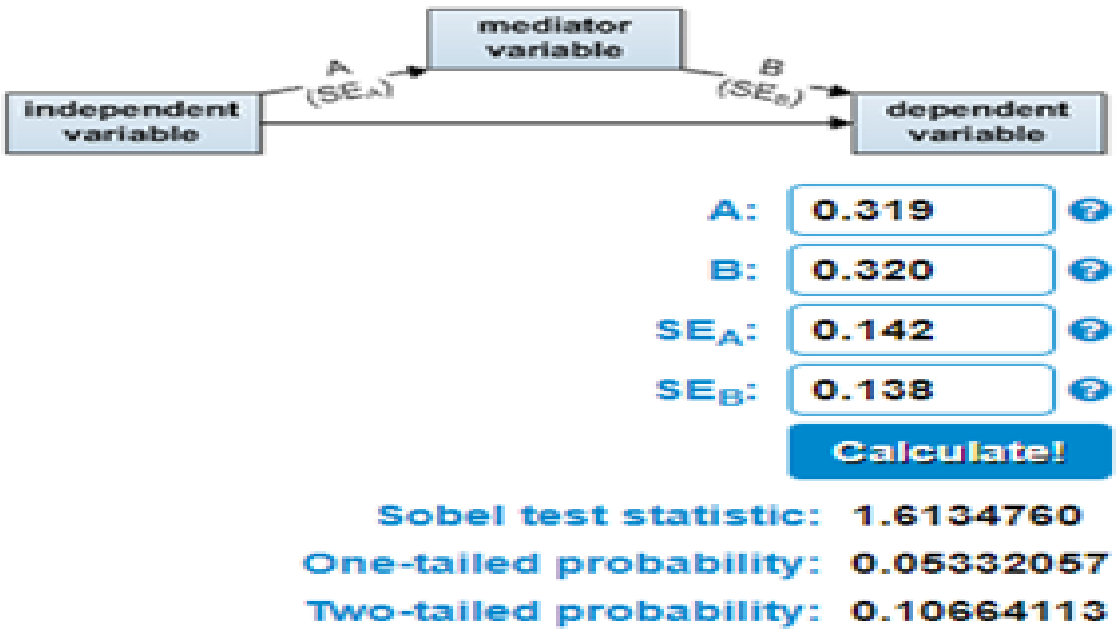

Fig. 3: The mediating role of job satisfaction: competence on performance

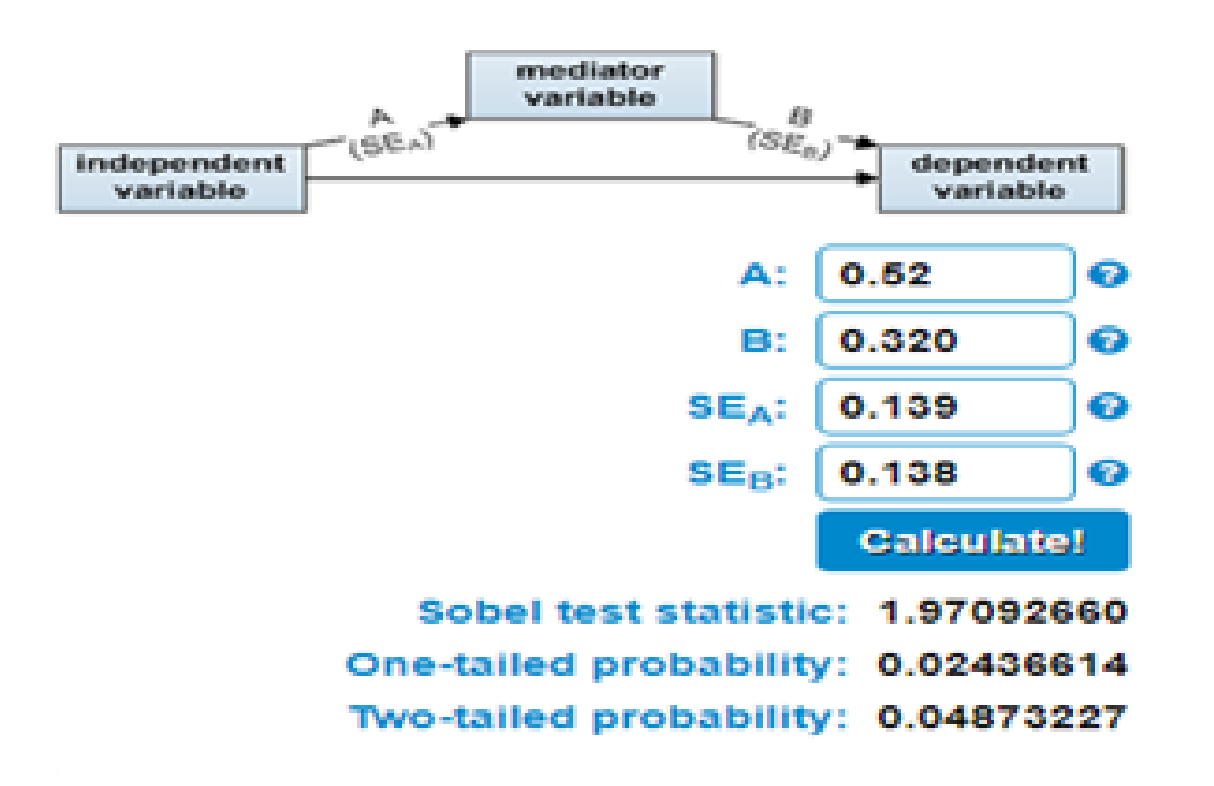

Fig. 4: The mediating role of job satisfaction: discipline on performance 


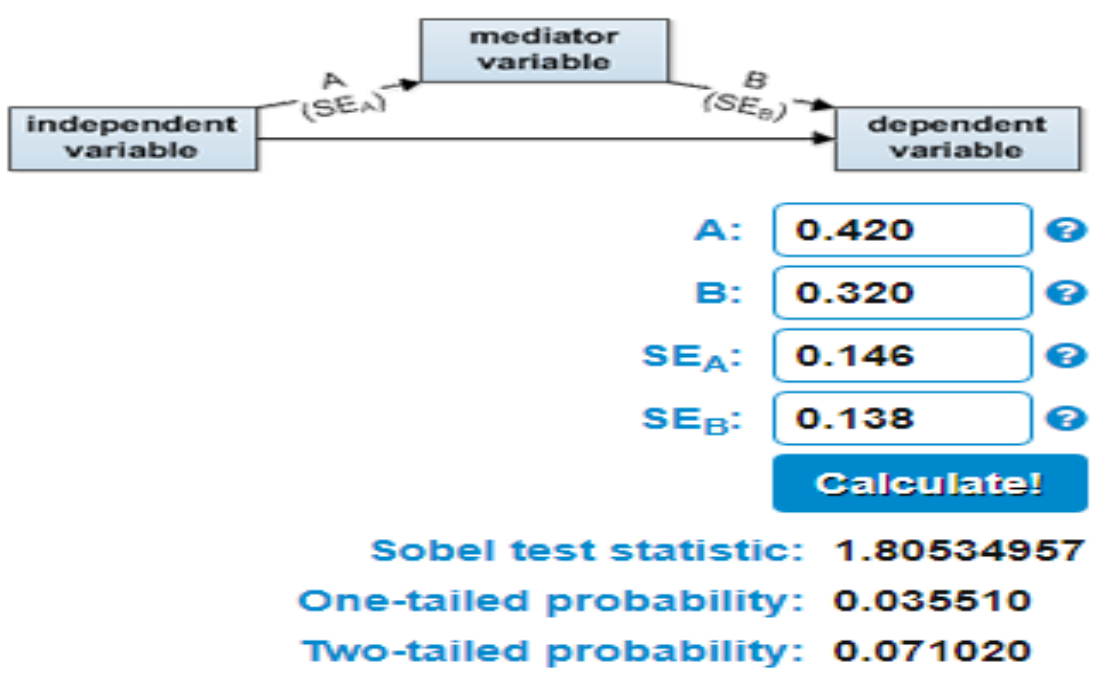

Fig 5: The mediating role of job satisfaction: emotional intelligence on performance

From the seven direct-path models and three hypothetical indirect paths, four direct lines have a positive and significant influence, while three direct paths provide positive and insignificant influences. For indirect influence, it appears entirely to have a positive and significant effect. Based on the above table it can be seen that there are six paths that influence all significant. Thus the hypothesis in this study respectively: $\left(\mathrm{H}_{1}\right)$ competency has a positive effect on job satisfaction, $\left(\mathrm{H}_{2}\right)$ emotional intelligence has a positive effect on job satisfaction, $\left(\mathrm{H}_{4}\right)$ competency positive effect on performance, $\left(\mathrm{H}_{7}\right)$ job satisfaction effect positive $\left(\mathrm{H}_{9}\right)$ discipline has a positive effect on performance through job satisfaction, and $\left(\mathrm{H}_{10}\right)$ emotional intelligence have positive effect on performance through job satisfaction, proven accepted and supported by empirical facts. Rejection of hypotheses based on the results of analysis, proved each through: $\left(\mathrm{H}_{2}\right)$ discipline has a significant effect on job satisfaction, $\left(\mathrm{H}_{5}\right)$ discipline has a significant effect on performance, $\left(\mathrm{H}_{6}\right)$ emotional intelligence has a significant effect on performance, and $\left(\mathrm{H}_{8}\right)$ positively affect the performance through job satisfaction, the four hypotheses are not proven or not supported by empirical facts.

The statement can be explained in the form of a brief interpretation as follows:

1. Competence has a direct positive and significant effect on job satisfaction with $\mathrm{p}=0.025$ $<0.05$ and coefficient value of 0.319 , this coefficient indicates that the employee in carrying out the activity of arranging local government budget indicate its competence and satisfied with the work it is doing. 
International Journal of Arts and Humanities

ISSN: 2581-3102

Volume:02, Issue:05 "May 2018"

2. Discipline has a direct positive and insignificant effect on job satisfaction with $p=$ $0.709>0.05$ and coefficient value of 0.052 , this coefficient indicates that there are still employees who have not disciplined in carrying out activities of local government budget preparation that affect job satisfaction.

3. Emotional intelligence has a direct positive and significant influence on job satisfaction with $p=0.004<0.05$ and coefficient value of 0.420 , this coefficient indicates that employees in carrying out activities of local government budget preparation apply emotional intelligence and satisfied with the work achieved.

4. Competence has a direct positive and significant effect on performance with $p=0.035$ $<0.05$ and coefficient value of 0.231 , this coefficient indicates that the employee in carrying out the activity of arranging local government budget shows its competence, thus affecting the achievement of performance.

5. Discipline has a direct positive and insignificant effect on performance with $p=0.262>$ 0.05 and coefficient value of 0.109 , this coefficient indicates that there are employees who have not disciplined in running local government budgeting activities that affect the achievement of performance.

6. Emotional intelligence has a direct positive and insignificant effect on performance with $p=0.355>0.05$ and coefficient value 0.095 , this coefficient indicates that the application of emotional intelligence has not had an effect on the improvement of employee performance.

7. Job satisfaction has a direct positive and significant effect on performance with $p=0,021$ $<0.05$ and coefficient value of 0.320 , this coefficient indicates that achievement of job satisfaction affects the improvement of employee performance.

8. Competence through job satisfaction has positive and insignificant on performance with coefficient indirect effect value of 0.141 . The result of by Sobel test was obtained 1,613 < 1,98 with the significance level of p-value $0.053>0,05$, proved that the competence shown by the local government budget compilers team had given job satisfaction, and indirectly had a significant effect on performance improvement.

9. Discipline through job satisfaction has a positive and significant on performance with the coefficient value of indirect effect of 0.016 . The result by Sobel test was obtained 1,970 $<1,98$ with significance level $p=0,024<0,05$, proved that the discipline shown by local government budget compilation team gave job satisfaction which indirectly had an effect on the performance improvement.

10. Emotional intelligence through job satisfaction has a positive and significant on performance with the indirect effect coefficient value of 0.139 . The result by Sobel test was obtained at $1.805<1.98$ with the significance level of $\mathrm{p}=0.036<0.05$, proving that 
International Journal of Arts and Humanities

ISSN: 2581-3102

Volume:02, Issue:05 "May 2018"

the emotional intelligence shown by the local government budget team gives job satisfaction which indirectly influences the performance improvement.

Analysis of relationship between variables in the model, was used to compare the effect of each variable constructs. The direct effect is the coefficient of all coefficient lines with one end arrow, whereas the indirect effect is the effect arising through an intervening variable while the total effect is the influence of the various relationships (Ferdinand, 2000: 139). The result of influence test is presented in table showing the magnitude of direct, indirect and total influence between variables.

\section{CONCLUSION}

1. Competence has positive and significant effect on job satisfaction of budget drafting teams. In general, employees in the work have the competence of knowledge, skills, experience and attitudes sufficient in carrying out work that causes employees to easily realize of Kolaka budget drafting team's job satisfaction. .

2. Discipline has a positive and insignificant effect on job satisfaction of budget drafting teams. In general, employees have performed appropriate work disciplines with craft, attendance, timeliness, compliance and imposition of sanctions, but have no implications in improving of Kolaka budget drafting team's job satisfaction.

3. Emotional intelligence has a positive and significant effect on job satisfaction of budget drafting teams. Generally employees have emotional intelligence based on selfawareness, self-regulation, self-motivation, empathy and social skills, so easy to realize of Kolaka budget drafting team's job satisfaction.

4. Competence has a positive and significant impact on the performance of the local government budgeting team. Competence owned by employees is very important role in improving the of Kolaka budget drafting team's performance.

5. Discipline has a positive and insignificant impact on the performance of the local government budgeting team. The form of discipline has not given real implication to the improvement of employee performance to make arrangement of local government budget. Emotional intelligence has a positive and insignificant effect on the Kolaka budget drafting team's performance

6. Emotional intelligence has been applied by employees but not directly related to the achievement of work as an assessment of Kolaka budget drafting team's performance.

7. Job satisfaction has a positive and significant impact on the performance of the local government budgeting team. Employees in carrying out their work have been satisfied, thus giving effect to the improvement of Kolaka budget drafting team's performance. 
International Journal of Arts and Humanities

ISSN: 2581-3102

Volume:02, Issue:05 "May 2018"

8. Competence through job satisfaction has a positive and insignificant effect on the performance of the local government budget team. The existence of competent employees is always correlated to job satisfaction in improving of Kolaka budget drafting team's performance.

9. Discipline through job satisfaction has a positive and significant impact on the performance of the local government budgeting team. The existence of a disciplined employee always correlates to his job satisfaction in improving of Kolaka budget drafting team's performance.

10. Emotional intelligence through job satisfaction has a positive and significant impact on the performance of the local government budgeting team. The existence of employees who show emotional intelligence always correlates to job satisfaction in improving of Kolaka budget drafting team's performance

\section{REFERENCES}

[1] Bennardin \& Russel. (2012). Organization Management and Peformance. Published by Prentice Hall, Ohio Press.

[2] Berdmend, John. (2007). Management and Discipline of Human Resource. Prentice Hall, New York.

[3] Cleveland, Musk. (2008). Performance. Published by Harper T \& Row, New York. Dekker, Mascule. (2007). Satisfaction and Application in Globalization Era. http://www.journalmotivation.com.id.

[4] Dessler, Gary. (2007). The Good of Culture Organization in Company. Published by Addison-Wesley Publishing Company.

[5] Donald, Michael. (2007). Human Resource Management. West Publishing Company, New York.

[6] Furtwengler, Dale. (2007). Attitudes Performance Organization. Englewood Cliffs, Prentice Hall, New Jersey.

[7] Gibson, James L, Ivancevich, John M. \& Donnely, James. (2004). Organizational Behavior, Structure, Process. 3rd, edt., Dallas, Business Publications, Inc.

[8] Gibson, James L. (2013). Human Resource Management. Translation: Djarkasih, Fourth Edition, Erlangga, Jakarta.

[9] Goleman, Daniel. (2002). Emotional Intelligence. PT Gramedia Pustaka Utama, Jakarta. Gully,

[10]Harry, Blumer. (2011). Competency of Human resource recruitment Organization. Englewood Cliffs, Prentice Hall, New Jersey. 
International Journal of Arts and Humanities

ISSN: 2581-3102

Volume:02, Issue:05 "May 2018"

[11] Hasanuddin, R., \& Sjahruddin, H. (2017). The Structure of Emotional Intelligence, Spiritual Intelligence and Its Relationship with Work Enthusiasm and Auditor Performance. World Journal of Business and Management, 3(1), 67.

[12] Hersey, Paul. (2007). Management for Human Resources. 4th. Ed. Englewood Cliffs, New Jersey, Prentice-Hall, Inc.

[13]Lincoln. (2008). Competence and Management. Routledge and Kegan Paul, London.

[14]Luthans, Fred. (2007). Organizational Behavior. New York, McGraw-Hill Book Company, 3rd, edt.

[15] Moore. (2011). Competence and Emotional Quotient toward Satisfaction and Performance by Employee in Malaysia. Research Journal of Recent Sciences. Vol. 1 (7), 59-67, July (2011) ISSN 2277-2502

[16] Prijodarminto, Soegeng. (2011). Discipline - Tips for Success, Publishers Pradnya Paramita, Jakarta.

[17] Rivai, Veithzal. (2008). Performance Appraisal. Rajawali Press Publishers, Jakarta

[18] Schemerhorn, French, Hunt, Briant, \& Osborn. (2007). Human Resource in Performance Management. 2nd Edition, Mas Hougton Mifflin Company, Boston.

[19] Stewart. (2010). Self Concept, Motivation and Competence in Increasing of Satisfaction and Performance by Employee in Texas America. Journal of Human Resource, Vol. 5, 1-10. http://google.com.

[20] Terry, George. (2008). Theories of Management Organization Application, Published by Thompson Press, USA.

[21] Walker, Hatt. (2007). The Role in Management, New York, John Wiley and Son Inc. 